\title{
6. Response and Responsibility: On the Cosmo-politics of Generosity in Contemporary Asian Art
}

\author{
Marsha Meskimmon
}

\section{Responding | Giving}

Between 1996 and 1997, Indonesian artist Dadang Christanto produced the sculptural installation They Give Evidence (Mereka Memberi Kesaksian). The work, funded through a grant from the Japanese Government, was first shown at the Museum of Contemporary Art in Tokyo and then travelled to the Hiroshima City Museum of Contemporary Art. In Japan, the installation consisted of 20 sculpted male and female figures arranged facing forward in four rows of five, ${ }^{1}$ each bearing in their outstretched arms the traces of bodies, rendered palpable in, and by, the folds and contours of clothing. The figures that comprise this work are eloquent in their simplified rendering: their eyes look straight ahead, their mouths are held as if ready to speak and their arms gently bear the weight of absent bodies while they stand unwavering, present with us, in the space. The striking bodily gesture that is made by these figures as they give evidence can be described as an offering, an open gesture toward those who may respond. The figures neither raise their hands to threaten, avenge or admonish, nor fold their arms to protect or exclude. They offer, they give.

This open and generous bodily signal is a fitting gesture with which to begin this essay, linking as it does the possibility of ethical generosity with the double play of response as both the sensory result of bodily perception and as a reply or answer to another. Responding is a key concept in relation to Christanto's practice and one that is frequently noted in criticisms of his work. Christanto's performances and sculptural installations are themselves understood as a response to trauma and, significantly, to have an unusual capacity to elicit explicit and immediate responses from their audience, without seeking these in a direct or, more to the point, directed way. That is, while Christanto does not see his work as complete without participation from viewers, the work does not include 'instructions' to participant-spectators telling them how to respond, nor is his practice 'participatory' in the sense of requiring the audience to undertake an action or set of actions to complete the work of art.

1 Four figures were acquired for the permanent collection in Tokyo. The remaining 16 figures were acquired by the Art Gallery of New South Wales in 2003 as a central focus of their Asian Galleries. 


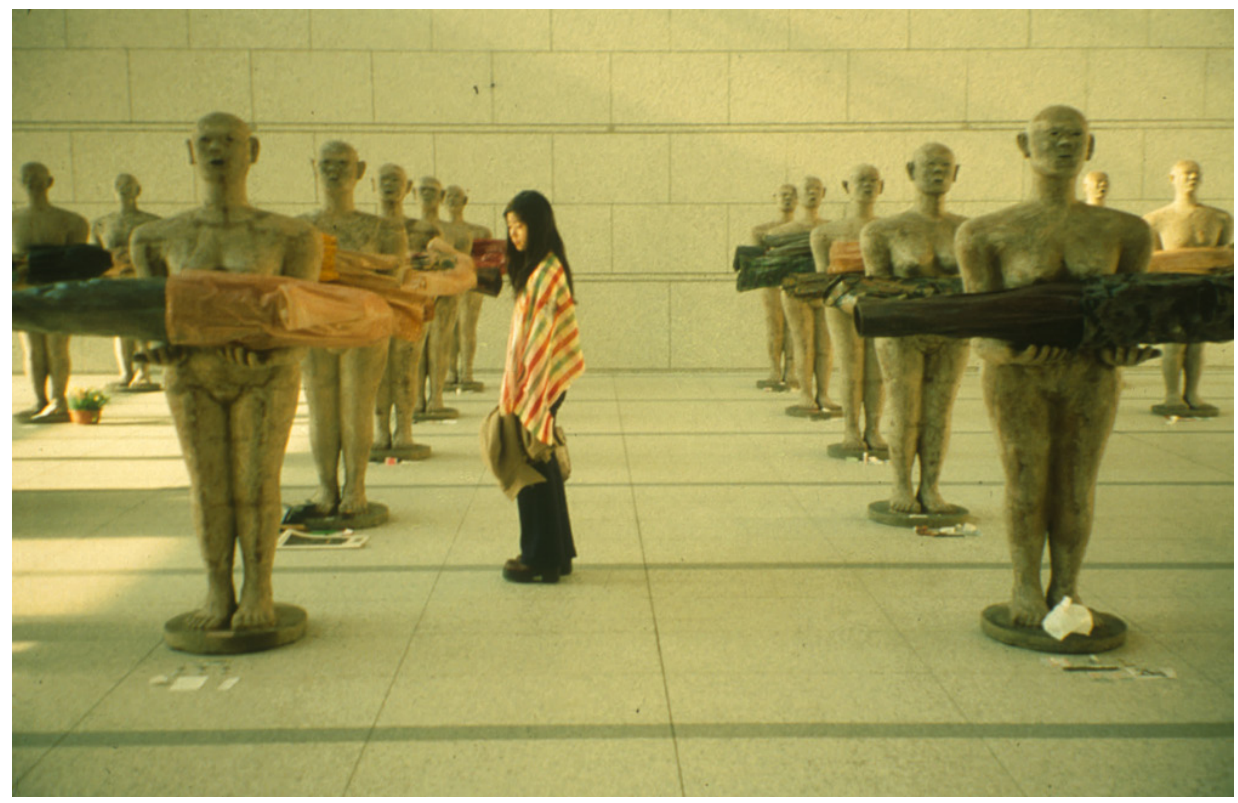

Dadang Christanto, Mereka Memberi Kesaksian (They Give Evidence) 1996-1997; installation view; exhibited at Museum of Contemporary Art, Tokyo and Hiroshima City Museum of Contemporary Art, 1997; standing figures holding clothes; terracotta powder mixed with resin/fibreglass, cloth and resin; height $200 \mathrm{~cm}$ (male), $190 \mathrm{~cm}$ (female), width and depth c. $100 \times 150 \mathrm{~cm}$, weight c. $90 \mathrm{kgs}$ each.

Collection: Museum of Contemporary Art, Tokyo and the Art Gallery of New South Wales, Sydney; reproduced by courtesy of the artist

Yet, the effect that Christanto's performances and sculptural installations have on their audiences is remarkable, especially the extent to which the works engender a vibrant, visceral and spontaneous response that often includes what can only be called 'offerings'. As Caroline Turner and Glen Barclay wrote of They Give Evidence: 'It had a major effect ... on Japanese audiences, who spontaneously left flowers and poems about universal suffering ...' . ${ }^{2}$ Turner and Barclay further note that responses to Christanto's work are international in their scope - they are not limited to this specific installation, or to Japanese audiences - and they describe a similar response from Australian viewers to an installation from $1993 .^{3}$ In their astute reading of such international responses, Turner and Barclay argue for the works' ability to link specific, regional events with universal experiences of human suffering, loss and grief.

2 Caroline Turner \& Glen Barclay, 'Dadang Christanto: Wounds in Our Heart', in Dadang ChristantoWounds in Our Heart, ed. Caroline Turner \& Nancy Sever (Canberra: The Australian National University, Drill Hall Gallery, 2010), 12. I would like to thank Turner for first making me aware of Christanto's work.

3 Ibid., 11. 
Christanto himself appears to concur with this understanding of the effect of his work on audiences internationally, suggesting, for example, that the response to They Give Evidence by individuals in Japan was to do with personal contexts of loss and with a wider sense of collective, national guilt in relation to the Japanese occupation of Indonesia during the Second World War. ${ }^{4}$

I am indebted to these insights concerning the imbrication of the regional and the global in the responses of spectators to Christanto's practice, and I seek here to develop these ideas in a different, but related, exploration of the twofold sense of response described above. To do so, it is important to think critically about the elements of the work to which participant-spectators have responded and the nature of that response. I want to suggest that it is significant that the responses to They Give Evidence have emerged across cultural and linguistic divides, that they connect the micro-stories of individuals with the macro-histories of global geopolitics, and that they find their most compelling form through unbidden giving. Arguably, these features constitute what might be described as a 'cosmopolitan' mode of responsibility, in which subjects simultaneously acknowledge the difference and specificity of others' experiences, yet respond generously to them.

Christanto makes no secret of the fact that a central impetus for his practice resides in a personal experience of traumatic loss; as an eight-year-old child in 1965, Christanto's father 'disappeared' during the violent anti-communist political struggles in Indonesia. His father never returned-he is one of the many 'disappeared' whose absence is mourned without resolution. They Give Evidence is but one of many works that Christanto has made in the wake of his personal experience of political violence, yet it is not a representation of particular events, nor in any sense directly illustrative of the Indonesian political context.

Significantly, when They Give Evidence was shown in Japan in 1997, and later, in the 24th Bienal de São Paulo in 1998 (where just six of the sculptural figures were shown) and from 2003, in the Art Gallery of New South Wales (where 16 figures form part of the gallery's permanent collection), audiences approaching the work have been made aware of the artist's biography. In other words, there is a narrative that accompanies They Give Evidence, however lateral its connection to the work may be. The narrative exemplifies the interweaving of the local and the global; its detail is specific to a particular time and place, but the overarching tale is not - a child losing his beloved parent in an act of unspeakable and unnameable ${ }^{5}$ violence has a universal resonance.

4 Sue Ingham, 'Witnesses from Indonesia', TAASA Review 12, no. 4 (December 2003): 22.

5 See Charles Merewether, 'Naming Violence in the Work of Doris Salcedo', Third Text 24 (Autumn 1993): 35-44; and, Griselda Pollock, After-Affects, After-Images: Trauma and Aesthetic Transformation in the Virtual Feminist Museum (Manchester University Press, 2013). 


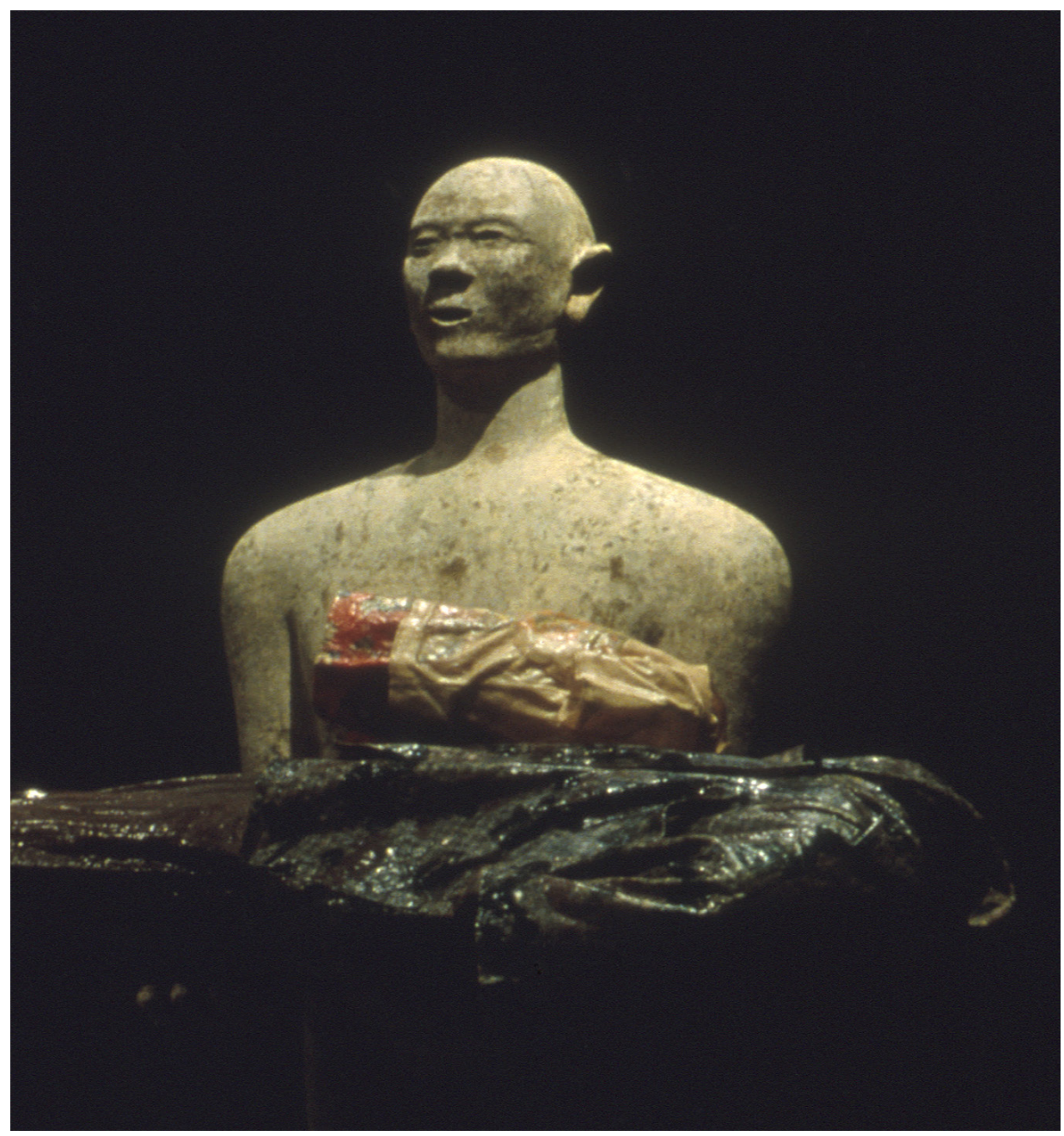

Dadang Christanto, Mereka Memberi Kesaksian (They Give Evidence) 1996-1997; installation view; exhibited at Museum of Contemporary Art, Tokyo and Hiroshima City Museum of Contemporary Art, 1997; standing figures holding clothes; terracotta powder mixed with resin/fibreglass, cloth and resin; height $200 \mathrm{~cm}$ (male), $190 \mathrm{~cm}$ (female), width and depth c. $100 \times 150 \mathrm{~cm}$, weight c. $90 \mathrm{kgs}$ each.

Collection: Museum of Contemporary Art, Tokyo and the Art Gallery of New South Wales, Sydney; reproduced by courtesy of the artist

Arguably, the audiences for this work in major metropolitan centres from Tokyo and Hiroshima to São Paulo and Sydney, daily hear tales of political violence, poverty and suffering on a global scale through televised news, print media and the tireless fundraising of charitable organisations. And while some news stories and charity 'infomercials' certainly hit their mark, producing an epiphanic 
moment of empathy, many do not. Thus, the unanticipated and spontaneous responses evoked by They Give Evidence cannot merely be attributed to the translation of a moving narrative in the gallery space, though this microstory does form one part of the experience of the work. I want to suggest that responding to They Give Evidence is, rather, at once a form of multi-sensory, kinaesthetic response to the transformation of grief and trauma into the affective aesthetic registers of art, and a compelling ethical response to the entreaty of another. It is at the level of these dual economies of response that art offers a potential crossing between cultural, linguistic and social boundaries - and a place in which we can imagine and respond to other people who are different from ourselves. It is here that the cosmo-politics of response can emerge.

If responding to They Give Evidence does not require a shared language, history or cultural tradition on the part of its international audience, the evidence of its ability to evoke such demonstrative responses begs further analysis. At what point and in what sense does the work provide conditions sufficient to engender collective engagement and a willing, proactive, display of emotion? As I see it, the start of the answer resides in the concept of bodily empathy, the operation of our proprioceptive capacities in an organised and orchestrated space. The figures in They Give Evidence are, literally, compelling; the rows of monumental human forms, both male and female, unique and yet collective in their orientation and gesture, beckon to us bodily, seeking a corporeal recognition. Our bodies come to understand the spatial dimensions of the work by moving around these other bodies, both absent and very present, and we are obliged to orient ourselves in connection with them, to understand and locate ourselves, proprioceptively, in relation to this collective act of corporeal witnessing, of giving evidence, of standing in an attitude of openness and entreaty. A proprioceptive engagement with the work brings us to our senses, resonates kinaesthetically, such that our bodies make sense of the work through gestural empathy; if we engage with the work (kin)aesthetically, we are compelled imaginatively to entertain an open gesture of offering in and through our own bodies. We give evidence, we entreat, we offer.

As Barbara Stafford has argued, kinaesthesia can be a compelling sensory state in that it connects sensation with cognition: 'We become aware of thinking only in those kinaesthetic moments when we actively bind the sights, savours, sounds, tastes and textures swirling around us to our inmost, feeling flesh.' ${ }^{6}$ With our bodily empathy in play in the space of They Give Evidence, we become responsive to the entreaty of the other, we can hear the evidence we are given, and we can be moved to respond in the second sense: we can offer our answer.

6 Barbara Stafford, Visual Analogy: Consciousness as the Art of Connecting (Cambridge, MA: MIT Press, 1999), 58. 
But, what is asked by They Give Evidence? Whom do we answer and how? The dual nature of response is again useful in thinking critically about this question. In addition to indicating a sensory awareness of our embodiment and our connections with other subjects and objects in the world, response implies an ethical or moral obligation to others. Response comes from the French, where the root retains the sense of a reply as an oath or obligation, an answering back that entangles us with the one who seeks our response.

If the premise of They Give Evidence is an aesthetic transformation of trauma into testimony, then these witnesses, amongst whom we may find ourselves located through kinaesthetic empathy, are not simply asking a question to which there is a definitive answer. Their entreaty operates instead as an open call to others for recognition. In this gesture, we are invited to bear witness, to share responsibility for the weight of the evidence that they offer. This does not entail accounting for or to (an 'answering back' that closes the generosity of the ethical relation), but impels a further giving. This is the nature of the response that has arisen spontaneously across divides of language, history and culture, by those who have engaged, bodily, with this work - and this response speaks volumes.

I am proposing here that both ethical responsibility and generosity are underpinned by an affective ability to respond, in the double sense, to the needs and demands of others. This interpretation accords with Kelly Oliver, who eloquently described the inter-relationship between response and responsibility in her book, Witnessing: Beyond Recognition, thus:

There is a direct connection between the response-ability of subjectivity and ethical and political responsibility. ... The responsibility inherent in subjectivity has the double sense of the condition of possibility of response, response-ability, on the one hand, and the ethical obligation to respond and to enable response-ability from others born out of that founding possibility, on the other. ${ }^{7}$

Neither response-ability, nor responsibility can be obliged, but they can be engendered, fostered and compellingly performed in and through the sensory registers of art. And if generosity and responsibility are necessary corollaries to justice, hospitality and forgiveness, then politics and ethics here converge at the point of an embodied, engaged and affective cosmopolitan subject.

7 Kelly Oliver, Witnessing: Beyond Recognition (Minneapolis, MN and London: Minnesota University Press, 2001), 15 . 


\section{Giving | Imagining}

How might we understand the progression from response to generosity, or from responding to giving, and what role might an imaginative engagement with art play in this unfolding? To begin to address this question, it is useful to turn to another work that has elicited strong responses across cultural boundaries: Araya Rasdjarmrearnsook's Reading for One Female Corpse from $1998 .^{8}$

The work consists of a single-channel video showing the artist, seated in the Chiang Mai Hospital morgue in Thailand, reading passages from the classical Thai text, the Inau, over the corpse of a young woman. The body of the unnamed young woman lies in a clear perspex container, covered from head to knee by white cloths. The intimate and visceral presence of the corpse is central to the piece, but her body is not rendered as an object of grotesque fascination. For most of the duration of the work, we watch the scene of the seated artist reading to the covered body at a slight distance, as a witness or fellow mourner might, rather than as a voyeur. And, even when the video pans along the length of the body, revealing the mottled skin surface of the woman's arms and legs, we are never privy to a fetishised, forensic visual dissection of the dead woman. The camera, accompanied by the low tones of the artist's reading, is gentle to this body; searching, but not probing.

Reading for One Female Corpse is one of a number of video works that Rasdjarmrearnsook made during the late 1990s and early years of the present century, for which she read, spoke, sang to or dressed corpses in the Chang Mai Hospital morgue. This complex and multifaceted body of work has been shown extensively throughout the world, in solo shows and major group exhibitions, such as the Venice, Sydney and São Paulo biennales and the Carnegie International. Sometimes the videos are shown individually and, at other times, they are configured as themed clusters. Tellingly, Reading for One Female Corpse has been grouped with other work under the title of Lament, ${ }^{9}$ placing the emphasis on the recitation for the dead woman rather than the representation of her body as an object within the work.

The act of recitation, the artist's solitary lament for the young woman whose body lies alone in the morgue, is central to the piece and critical to the argument being developed here concerning the complex imbrication between responding and giving that is articulated by Reading for One Female Corpse. The Inau is not a traditional Thai funeral lamentation, but a classical literary work of the

8 There are discrepancies in the dating of this piece; in some sources it appears as 2001, though it is clear that it was shown as early as 2000 . For this reason, I am using the earlier date.

9 The collective title Lament was used, for example, when the work was shown in Sweden, at the Edsvik Museum in Stockholm, in 2000. 
eighteenth century originating in Java and having been brought to Thailand via Malaya. It is the story of a prince and his courtship of three women and includes long passages in which the women's longing and sexual desires are voiced. These are elements of the Inau, which are well known to Thai audiences, that Rasdjarmrearnsook reads as her lament to the young woman. Reading for One Female Corpse thus makes an explicit link between female sexuality, subjectivity, desire and death.

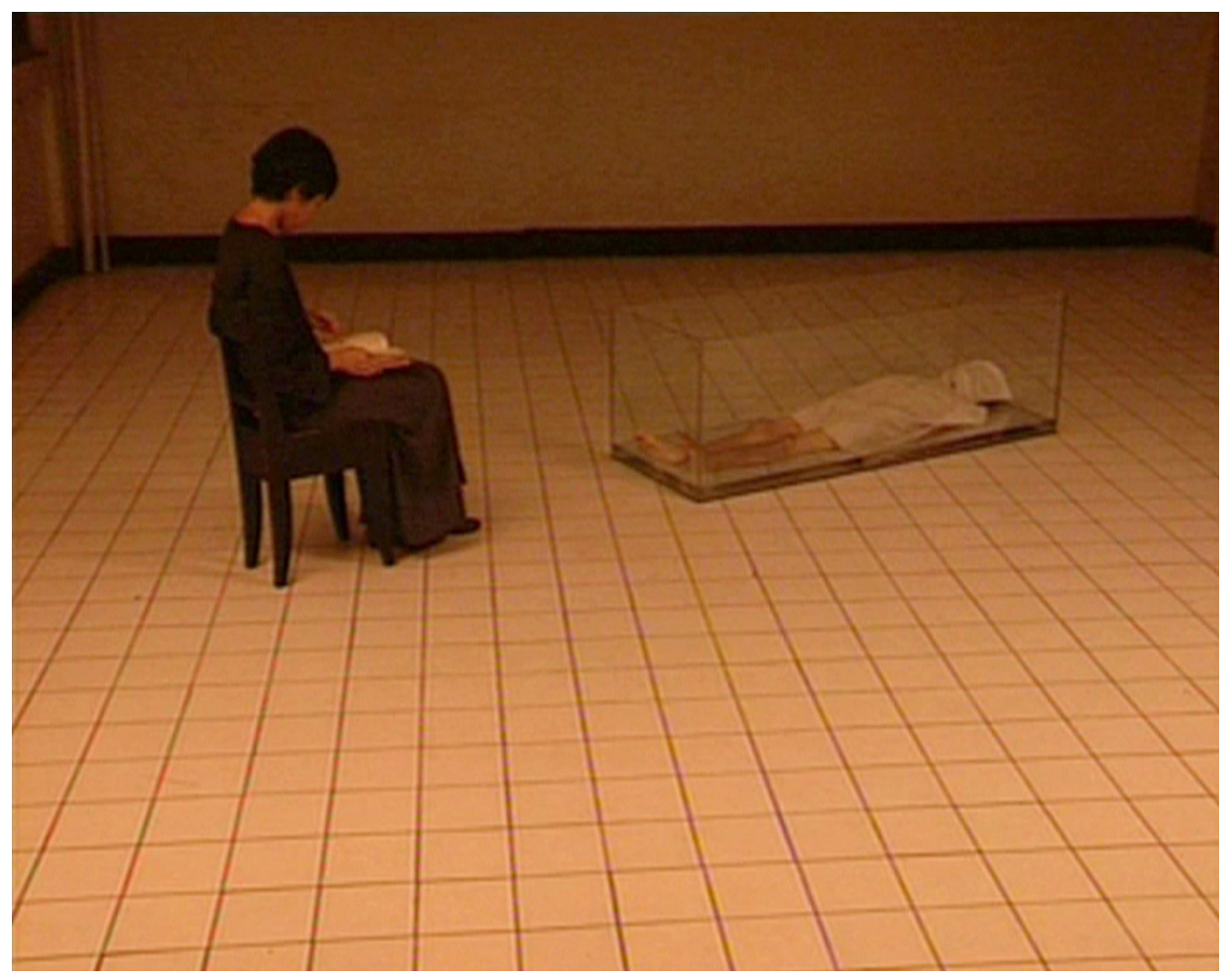

\section{Araya Rasdjarmrearnsook, Reading Inaow for Female Corpse (Lament Series) 1997; video.}

Work and image courtesy: Araya Rasdjarmrearnsook, with kind assistance of 100 Tonson Gallery, Bangkok

Arnika Fuhrmann has argued convincingly that Rasdjarmrearnsook's lamentations over anonymous corpses in the Chiang Mai Hospital morgue not only raise the question of sexual difference in the textual sources, some of which are the artist's own writings, but in the highly resonant act of female lamentation. ${ }^{10}$ Historically, the lengthy duties of public lamentation, which were central to Thai funeral traditions, were undertaken by women. Only in

10 Arnika Fuhrmann, 'Ghostly Desires: Sexual Subjectivity in Thai Cinema and Politics after 1997' (PhD thesis, University of Chicago, 2008), 234. 
recent times has an established male Buddhist hierarchy dislocated female voices from their active participation in the processes of mourning, rendering women members of the unseen and silent labour force that prepares bodies (cleans and dresses them) but does not sing their desires through the rituals of death. Reading for One Female Corpse thus enacts a double sense of voice. Acknowledgement is key to the Thai concept of a 'good death'; the anonymous, unclaimed body over whom Rasdjarmrearnsook recites from the Inau, is, in this generous act, reclaimed, voiced and acknowledged in her full, desirous, sexed subjecthood. And, likewise, the mourner's female voice is heard, and recognised, through this intonation of unbidden generosity.

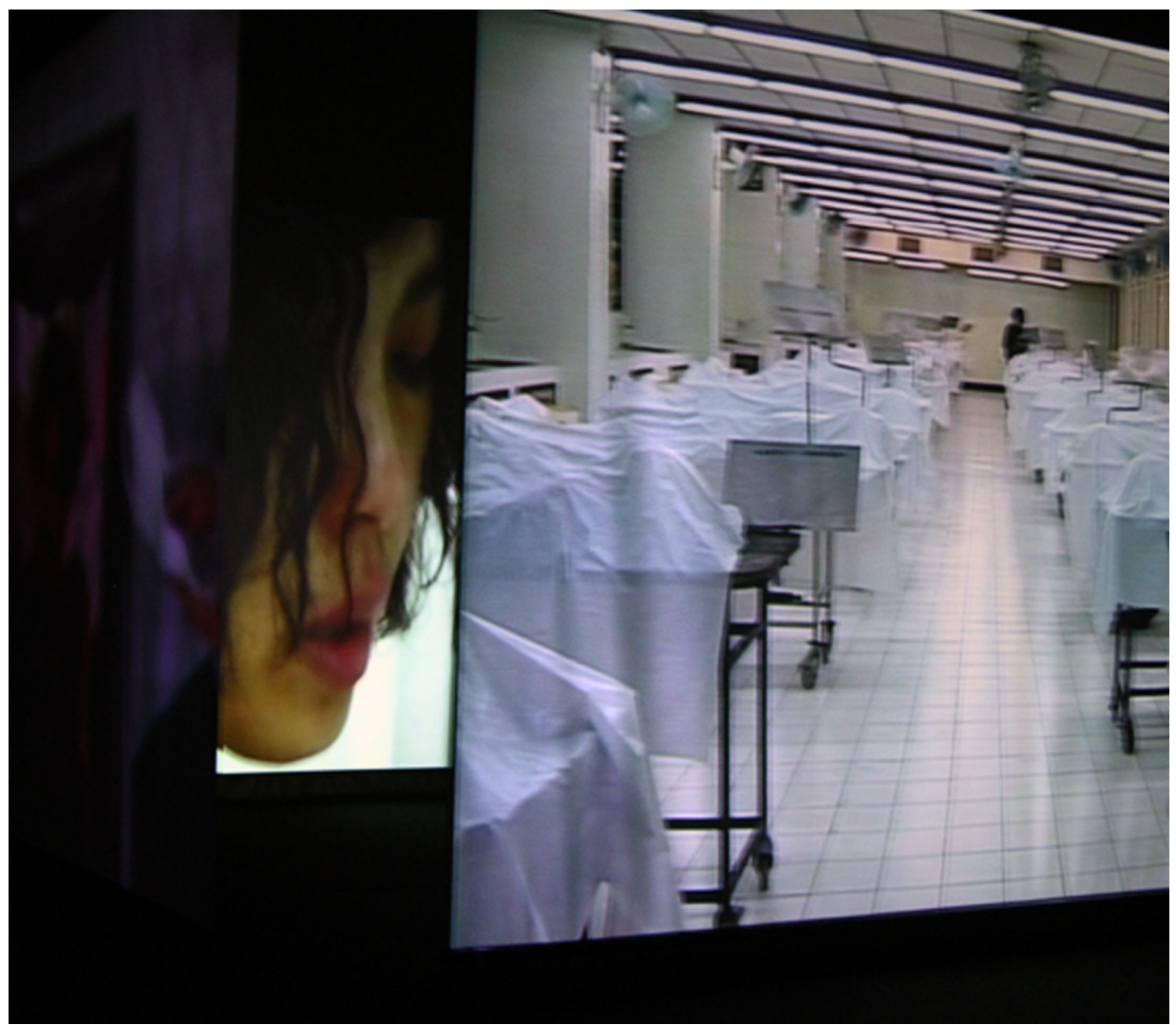

\section{Araya Rasdjarmrearnsook, Lament 1998; 3 single screens / video installation.}

Work and image courtesy: Araya Rasdjarmrearnsook, with kind assistance of 100 Tonson Gallery, Bangkok

As one might anticipate, Rasdjarmrearnsook's readings for corpses have engendered strong responses from audiences globally, but the strength of the response does not render it uniform. On occasion, within Thailand particularly, 
the works have been met with derision; ${ }^{11}$ the subject has been said to be too feminine, too personal and too local to give the artwork an appropriate gravity. As many international critics (and Rasdjarmrearnsook herself) have noted, much of this criticism has come from a male art establishment and professional jealousy may well play a part in this response. I want to suggest, however, that there is a more complex failure of response at the core of these critiques, such that the failure to respond to the work perceptually negates its potential to engender a response to its entreaty.

Reading for One Female Corpse has been problematic for those viewers at a local level ${ }^{12}$ who cannot, or will not, move beyond its literal subject matter, to engage with it as a work of art, a space in which we might reimagine the impact of everyday violence and destitution on others who are not, in fact, so distant or different from ourselves. For some viewers, a woman artist sitting in a morgue reading to the body of a young woman who, in life, was so insignificant as to be anonymous and unclaimed on her death, is too base a material from which to make 'art'. Thus read, the work engenders negative criticism for what it represents.

Remaining at the level of representation in encountering this work (where 'representation' is understood as the mirror of an external 'reality') renders an aesthetic response - an embodied and multi-sensory response - to what the work materialises as art, all but impossible. Yet, Reading for One Female Corpse is an artwork, not a documentary exposition of a particular social problem; the artist stages, films and edits a performance, constructing an aesthetic event with attention to the visual, sonic and spatial qualities of the work. This point is significant because it sustains the logic of the analysis of Reading for One Female Corpse as art, so as to critically evaluate the move from imaginative responseability to ethical responsibility and subjective generosity.

Notwithstanding these few negative responses, Rasdjarmrearnsook's video works in which she read for corpses have been lauded by international critics and have been included in curatorial projects globally. Across national, cultural and linguistic divides, viewers have frequently expressed a profound sense of being moved by Rasdjarmrearnsook's video lamentations - the works provoke positive responses in different geopolitical contexts.

11 Fuhrmann uses the word 'derision' in a discussion of Rasdjarmrearnsook's satirical response to her critics between 2003-2004; Ibid., 247.

12 The issue of local interpretation is important: as discussed earlier, the Indonesian political context of Christanto's They Give Evidence yields with relative ease to more universally applicable interpretations. But it is significant that They Give Evidence was difficult to show in Indonesia where, in 2002, the figures' nudity had to be shrouded before an exhibition of the work, and the work was subsequently removed altogether before the event opened. In the context of a growing political accommodation of Islamic fundamentalism in Indonesia since 1998, the work took on a differently 'politicised' cast. 
Two viewers' responses to the installation of Reading Inaow ${ }^{13}$ for Female Corpse at the 54th Carnegie International (2004-2005) in Pittsburgh are suggestive:

\begin{abstract}
Araya Rasdjarmrearnsook's (born in Trad, Thailand) Reading Inaow for Female Corpse is a disturbingly moving installation that includes a single chair facing a video projection of the artist reading Inaow (an ancient Thai text on female desire) to a decomposing female corpse. ... Rasdjarmrearnsook's melodic reading of the text is mesmerizing and comforting ... [the artist] forces individual viewers to contemplate death by making them a part of her ceremony...$^{14}$
\end{abstract}

Araya Rasdjarmrearnsook's Reading Inaow for Female Corpse was just beautiful in a very touching way ... ${ }^{15}$

These responses are not 'professional', in the sense of commissioned critical writing for art journals, exhibition catalogues or academic publications; rather, these writers have felt compelled by their experiences of the work to commit to writing to speak to others about being moved by Reading for One Female Corpse. In terms of their experience, the language they use is striking in its sensory resonance: 'disturbingly moving', 'mesmerizing and comforting', 'in a very touching way'.

How does this work of art touch viewers and to what effect? Arguably, the perceptual play of proximity and distance evoked by the work is critical to its ability to touch/move viewers and this play operates kinaesthetically, engaging subjects through their embodied responses to the piece. These responses are powerfully motivated by the multi-sensory qualities of the installed work as it combines immersive and resonant sound with haptic visuality in an intimate spatial configuration. Responding to the work in this sense moves beyond representation, toward an imaginative and intercorporeal form of response-ability.

Installed in Pittsburgh, Reading Inaow for Female Corpse was projected onto a wall in a small, darkened space. Facing the screen was a single chair, over which hung the translucent bell of the audio speaker; seated alone in the space, on the chair, the 'viewer' became a 'participant' in the recitation, not simply watching the performance, but being immersed in the sound of the reading. The sonorous incantation of the lament as it articulated women's desirous, corporeal subjectivity, acknowledged within the space of the performance both the reader, who came to voice, and the subject who came, in death, to be recognised.

13 In the Carnegie International, curated by Laura Hoptman, the work's title included a direct reference to the Inau, transliterated as Inaow.

14 Lyz Bly, 'Feeling the Zeitgeist: The 54th "Carnegie International" is Worth the Drive to Pittsburgh' (5 January 2005), http://www.newsenseonline.com/1_FT_2005_01_05.html.

15 gwenix, ‘A Bit of Cotton Doesn't Equate Fluff. - International Art Exhibit @Carnegie’ (12 February 2005), http://gwenix.livejournal.com/373741.html. 
Seated in a mirror image of the position of the artist reading from the Inau, enveloped by the concentrated sound and visually focused on the brightly lit projection, participant-spectators were kinaesthetically positioned by the work, such that the wall of the gallery perceptually yielded to the space of the Chiang Mai Hospital morgue, and participant-spectators were left sitting with Rasdjarmrearnsook as she intoned her lament over the body of the young woman.

The treatment of the body of the anonymous woman, within the artist's performance and within the frame of the video, is significant to the work's ability to engender a kinaesthetic empathy among viewers; more strongly, I would propose that it is first in the haptic visuality of the video that we are 'touched' by the work, and that this touching establishes the subjects who are articulated through the piece (including the artist, the dead woman and the viewers) as permeable and interconnected with others: response-able and responsible.

Rasdjarmrearnsook's readings for corpses were produced in the wake of more than one artworld controversy concerning the deployment of human corpses within lens-based practices; as early as 1992-1993, Joel-Peter Witkin's still-life compositions using human body parts, and Andres Serrano's Morgue series were at the centre of heated debates concerning the ethical implications of making art with unclaimed, anonymous corpses. Without rehearsing those arguments again here, and without suggesting that the projects undertaken by Witkin and Serrano were in any sense alike, ${ }^{16}$ the visual strategies they employed provide a useful point of comparison with those deployed by Rasdjarmrearnsook. In addition, it is likely that a proportion of the viewers of Reading for One Female Corpse, when it was shown in international biennials and group exhibitions, would have been familiar with these projects and/or the controversies that attended them. Moreover, international viewers aware of contemporary Asian art would likely have been reminded of the controversy caused in 2000 by Chinese artist Zhu Yu when he exhibited documentary photographs from his 'foetus-eating' performance Eating People in the Shanghai show Fuck Off. Zhu Yu was subject to investigations by both the FBI and Scotland Yard when images from this work circulated on the internet and were shown in a Channel 4 (United Kingdom) documentary on Chinese art. ${ }^{17}$ While Zhu's work tested the limits of

16 Witkin's works with corpses form part of a much larger body of images centred on the visual excess of the histories of the exhibition of 'monsters' and the 'freak show'; the ethical questions raised by his access to corpses in Mexico, not to mention the treatment of the bodies and body parts by the artist in the staging of the compositions, have been discussed elsewhere (see Ann Millett, 'Performing Amputation: The Photographs of Joel-Peter Witkin', Text and Performance Quarterly 28, nos 1-2 (January 2008): 8-42). Serrano's Morgue series does not locate the anonymous bodies within the context of the display of 'monsters', and there are not the same ethical issues involved in his access to the corpses. The question of the aestheticisation and objectification of the dead (many of whom met violent ends), however, still meant that his series courted controversy. See Anna Blume's interview with Serrano in BOMB 43 (Spring 1993), http://bombsite.com/ issues/43/articles/1631.

17 I would like to thank Michelle Antoinette for pointing out to me the relevance of Zhu Yu's work to contemporary viewers. 
conventional morality and law at the point of the foetal hinterland between human cells/flesh and 'personhood', the use of corpses by Witkin, Serrano and Rasdjarmrearnsook operated at the other end of the spectrum, exploring personhood (our own and others') post-mortem.

There are three central differences between the visual treatment of the dead body in Reading for One Female Corpse and the works of Witkin and Serrano that are critical to our potential response, as viewers, to Rasdjarmrearnsook's video: the absence of visual fragmentation of the body, the absence of a fixed, disembodied viewpoint or frame, and the presence, in the space of the performance and video, of the artist. One of the most shocking elements of Witkin's photographic use of corpses is his consistent emphasis on the dismemberment of the body; the works are frequently composed of pieces of bodies, severed roughly and juxtaposed so as to reinforce our sense of estrangement from these corporeal, yet inhuman objects. Serrano's morgue compositions fragment the bodies with the lens of the camera; through close focus and framing, we are given just blackened fingertips, or bruised cheeks, or a long abdominal scar.

The body fragments, which are central to the work of Witkin and Serrano, produce a distanced and disembodied viewpoint, even when the lens brings the viewer astonishingly close to the corporeal remains. We are able to look, voyeuristically, or be turned away, uncomfortably, from the abject fragments of others that are presented to us as aesthetic objects. By contrast, the corpse we encounter in Reading for One Female Corpse is seen first as whole, covered by clean, white cloths; when the camera pans across the skin of the woman's body, it is moving, the frame of any particular view of the flesh is constructed as a detail of the whole. It alights gently upon the skin, touches the surface, renders it palpable. This visual structure embodies the eye of the lens, gives it a location from which it encounters this body from within the same space, rather than from a fictional, distanced, objectifying beyond. And this is all the more strongly materialised through the unconditional presence of the artist, maintained audibly even when the camera places her body out of spectatorial view.

As a work of art, Reading for One Female Corpse mobilises sound, light, image and space to bridge objectifying visual distance and bring participantspectators into a proximate, haptic relationship with the bodies of the artist and the dead woman. Responding to the work perceptually, through a form of heightened kinaesthetic resonance, opens us to respond, ethically, to the entreaty of the other - in this instance, to recognise the woman who has died, not as a gruesome and abject object to be kept at a safe distance from us, but as a subject whose death implicates each of us in life. Indeed, the bodies brought viscerally and vitally together by the work - the artist, the dead woman and the viewer(s) - are positioned as intercorporeal subjects through this work and 
its pivotal gift of the lament. Our response-ability to this unrecognised other generates a corporeal responsibility to recognise her; the generosity of the artist's reading becomes an act of reclamation in our space.

This sense of generosity is materialised within the work as the condition by which subjectivity emerges in and through its fundamental interconnectedness with others. And such generosity is premised upon our embodiment and ethical entanglement, or 'response-ability' to and 'responsibility' for, other subjects in the world. Such giving is not easy, as Rasdjarmrearnsook wrote in a poetic accompaniment to her readings for corpses, and requires an effort, the assumption of the weight of responsibility: 'The air perfumed by death was so sad. Forcing herself, the weak one made the effort to be Giver. She then voiced a melodic strain $\ldots{ }^{\prime}{ }^{18}$

Reading for One Female Corpse establishes aesthetically the interrelationship between subjectivity, affect and generosity that Rosalyn Diprose has described so eloquently as the premise of ethical social relations. Diprose speaks of 'being given to others without deliberation in a field of intercorporeality, a being given that constitutes the self as affective and being affected, that constitutes social relations and that which is given in relation.' ${ }^{19}$ This is, in the artwork, materialised as the gift of recognition in and through difference. The logic of the gift is maintained in the haptic touch of the camera and the immersive song of the lament, which neither objectify the dead woman nor assimilate her to our experience; we recognise her and ourselves as connected, yet not the 'same'. Intercorporeal generosity unfolds from responding, from answering the call of the other. Our subjectivity is premised upon the response-able and responsible relationship we maintain with others in the world and, in this, we see the potential of a cosmopolitan ethical subjectivity.

The unnamed woman for whom no one laments touches us - through the artwork - and this touching constitutes us as embodied and permeable. As an abject object of representation, she is unrecognisable, unable to be articulated, a Jane Doe to whom we can give nothing but our voyeuristic attention. When we are touched, however, we are moved, compelled differently in our subjecthood. Here subjectivity responds to the entreaty of the other; we can recognise, we can give.

This giving establishes social bonds, but it is not synonymous with legislative or political action in the conventional sense. I am interested here in the effects that the affective economies of art can have at the level of the subject, and how these can compel action, but I am not confusing this with artworks being used, for

18 Rama IX Art Museum, 'Araya Rasdjarmrearnsook, Thai Artists', http://rama9art.org/araya/index.html.

19 Rosalyn Diprose, Corporeal Generosity: On Giving with Nietzsche, Merleau-Ponty and Levinas (Albany, NY: State University of New York Press, 2002), 5. 
example, to campaign for specific political purposes. My propositions are both more limited in their scope and more demanding in their critique. Rather than propose that artworks can change the world for the better if they follow certain strategies in their production, formal means and consumption, this exploration of the relationship between response, responsibility and generosity seeks to identify how our embodied and perceptual engagement with art can position us as subjects, open and responsive to encounters with people in the world who are very different to ourselves.

Engendering such an attitude, subjectively, has important ethical and political ramifications at a micro-level. I see these as being akin to the practices of 'critical responsiveness' that Stephen K. White has argued may underpin a more generous geopolitical pluralism:

And it is the practice of such a micropolitics of critical responsiveness that is necessary to engender a pluralism more generous than one operating only with more traditional liberal understandings of tolerance and justice. ${ }^{20}$

It is not insignificant that feminists who have sought to explore a critical ethics of care in the field of international relations, such as Fiona Robinson, have pointed to 'responsibility and responsiveness' as practices - modes of subjective engagement that can be fostered, but not forced. ${ }^{21}$ Nor is it surprising to find that feminist philosophers, exploring the possibility of an ethics of (sexual) difference, also focus on generosity, affect and imagination. ${ }^{22}$ Practices of response-ability configure our identities through forms of imaginative empathy and generosity that connect us, bodily, with others. Or, as Moira Gatens and Genevieve Lloyd have argued:

Our identities become determinate through processes of sympathetic and imaginative identification which respond to our present; these responses happen in a context set by our consciousness of our past, still present to us in bodily awareness. The ongoing forging of identities involves integrating past and present as we move into the indeterminate future; and the determining of identities is at the same time the constitution of new sites of responsibility. ${ }^{23}$

\footnotetext{
20 Stephen K. White, Sustaining Affirmation: The Strength of Weak Ontology in Political Theory (Princeton and Oxford: Oxford UP, 2000), 124.

21 Fiona Robinson, Globalizing Care: Ethics, Feminist Theory and International Relations (Boulder, CO and Oxford: Westview Press, 1999), 38, 39.

$22 C f$. Diprose, op.cit. and Luce Irigaray, An Ethics of Sexual Difference (London: Continuum, 2004).

23 Moira Gatens \& Genevieve Lloyd, Collective Imaginings: Spinoza Past and Present (London \& New York: Routledge, 1999), 80.
} 
The ability to respond is connected to political and ethical responsibility, and generosity emerges at the point where our kinaesthetic response compels us to answer the entreaty of another. Arguably, both They Give Evidence and Reading for One Female Corpse can be understood to have materialised this dual sense of response, such that participant-spectators, in different cultural contexts, are moved by the works and compelled to respond generously to their entreaty. The affective qualities produced by the works as art, enable spectators to engage with embodied others, different from themselves, through forms of kinaesthetic empathy and imaginative identification. These works have crossed worlds, eloquently articulating local, Asian experiences of loss, mourning and reclamation while, at the same time, communicating fluently with global audiences. Responding to difference by recognising others in their specificity acknowledges our permeability as embodied subjects, interdependent and interconnected with others. We are embedded in multiple forms of sociability and share multiple forms of responsibility. Cosmopolitanism is predicated on response and responsibility, as well as on corporeal generosity and the significance of imaginative identification. It is my contention that art can foster just such generous and imaginative forms of intersubjective sociability, and thus move some way toward the hopeful position of Gatens and Lloyd:

On this view 'world citizenship' does not involve an 'idealistic', or unattainable, transcendence of embodied being, but rather an immanent, embodied and ongoing negotiation between multiple forms of sociability. ${ }^{24}$ 
This text taken from Contemporary Asian Art and Exhibitions: Connectivities and world-making, by Michelle Antoinette and Caroline Turner, published 2014 by ANU Press, The Australian National University, Canberra, Australia. 